\title{
PENGARUH SUHU DAN UMUR PANEN TERHADAP MUTU \\ TAUGE (Phaseolus radiates) SELAMA \\ PENYIMPANAN DINGIN
}

\section{EFFECT OF TEMPERATURE AND AGE OF HARVEST OF QUALITY BEAN SPROUTS (Phaseolus radiates) DURING COLD STORAGE}

\author{
Cut Hospita Lisa ,Bambang Sukarno Putra, Ichwana \\ Program Studi Teknik Petanian, Fakultas Pertanian, Universitas Syiah Kuala
}

\begin{abstract}
Abstrak. Tauge kacang hijau yang sering kita konsumsi mengandung banyak gizi yang bermanfaat bagi tubuh kita, tapi termasuk jenis sayuran yang mudah rusak. Untuk meminimalisir tingkat kerusakan dilakukan percobaan menggunakan metode penyimpanan dengan jenis plastik pengemas Strech film dengan 3 variasi umur panen yaitu umur panen 3 hari, umur panen 5 hari dan umur panen 7 hari serta disimpan pada 3 variasi suhu $\left(4^{\circ} \mathrm{C}, 7^{\circ} \mathrm{C}\right.$ dan $\left.30^{\circ} \mathrm{C}\right)$. Hasil penelitian diperoleh perlakuan terbaik tauge untuk parameter susut bobot, total padatan terlarut selama penyimpanan 10 hari terdapat pada suhu $7^{\circ} \mathrm{C}$ variasi umur panen 3 hari dengan persentase susut bobot $15.80 \%$, total padatan terlarut $10.2 \%$ Brix, Vitamin C 1.76 mg, Kalsium 0,21 \%, organoleptik warna 3,75, organoleptik aroma 3,55, organoleptik penerimaan keseluruhan 3,55. Hasil perhitungan Menghitung Coefficient Of Performance (COP) menunjukkan bahwa pada suhu $7^{\circ} \mathrm{C}$ dengan nilai COP 2,45 paling tinggi nilainya dibandingkan suhu $4^{\circ} \mathrm{C}$ dan energi yang dilepaskan atau beban pendinginan yang harus didinginkan oleh mesin pendingin pada suhu pendinginan $4^{\circ} \mathrm{C}$ paling besar yaitu $236,6 \mathrm{~kJ}$.
\end{abstract}

Kata kunci : Tauge Kacang hijau, Umur Panen, Suhu

\begin{abstract}
Mung bean sprouts are often we consume contain many nutrients that are beneficial to our bodies, but including the types of vegetables that are easily damaged. To minimize the extent of damage done experiments using the storage method with a type of plastic packaging Stretch films with 3 variations of harvesting are harvesting three days, harvesting age 5 days and time of harvest 7 days and stored at three variations of temperature $\left(4^{\circ} \mathrm{C}, 7^{\circ} \mathrm{C}\right.$ and $\left.30^{\circ} \mathrm{C}\right)$. The research result was the best treatment parameters bean sprouts for weight loss, total soluble solids during storage of 10 days at a temperature of $7^{\circ} \mathrm{C}$ variations are harvesting three days with weight loss percentage of $15.80 \%$, amount dissolved solids $10.2 \%$ Brix, $1.76 \mathrm{mg}$ Vitamin C, Calcium $0.21 \%$, 3.75 organoleptic color, aroma organoleptic 3.55, 3.55 organoleptic overall acceptance. The results of calculations Calculating Coefficient Of Performance (COP) show that at temperatures $7^{\circ} \mathrm{C}$ with the highest value of $2.45 \mathrm{COP}$ value than $4^{\circ} \mathrm{C}$ temperature and the energy released or cooling load to be cooled by the engine coolant temperature cooling greatest $4^{\circ} \mathrm{C}$ is $236.6 \mathrm{~kJ}$,
\end{abstract}

Keywords: Bean sprouts, Harvest, Temperature

\section{PENDAHULUAN}

Tauge adalah tumbuhan kecil yang baru tumbuh dari biji kacang hijau melalui perkecambahan. Kecambah yang dibuat dari biji kacang hijau disebut tauge. Vitamin yang ditemukan dalam tauge adalah vitamin $\mathrm{C}$, thiamin, riboflavin, niasin, asam pantothenik, vitamin B6, folat, kolin, $\beta$-karoten, vitamin A, vitamin E ( $\alpha$-tokoferol), dan vitamin K. Mineral yang ditemukan dalam tauge adalah kalsium $(\mathrm{Ca})$, besi $(\mathrm{Fe})$, magnesium $(\mathrm{Mg})$, fosfor $(\mathrm{P})$, potasium $(\mathrm{K})$, sodium $(\mathrm{Na})$, zinc $(\mathrm{Zn})$, tembaga $(\mathrm{Cu})$, mangan $(\mathrm{Mn})$, dan selenium $(\mathrm{Se})$ (Maulana, 2010) 
Pengemasan sayuran segar bertujuan untuk mengurangi kehilangan kandungan air dengan demikian dapat mencegah terjadinya dehidrasi, terutama jika digunakan bahan penghalang yang kedap uap air. Hal ini dapat mempertahankan umur komoditas karena turunnya kandungan air akan menyebabkan kelayuan pada bahan yang merupakan sebab hilangnya kesegaran. Penggunaan plastik sebagai bahan kemasan buah-buahan dan sayuran dapat memperpanjang masa simpan produk hortikultura segar, di mana kemasan plastik memberikan perubahan gas-gas atmosfer dalam kemasan itu sendiri (Setyadjit,1992).

Menurut Ashari, 2006, Penyimpanan yang biasa dilakukan ialah dalam refrigerator atau ruang pendingin. Cara ini sangat efektif untuk mencegah kerusakan hasil panen. Jenis tanaman sayur, seperti buncis, selada, tauge, serta sayuran lainnya baik disimpan pada suhu rendah atau pada kondisi sejuk (di bawah $10^{\circ} \mathrm{C}$ ) karena bisa mengurangi kerusakan hasil panen yang disebabkan oleh mikroorganisme.

Selama ini masih banyak masyarakat yang memanen tauge dengan tidak memperhitungkan umur panen yang tepat untuk komoditi tauge dan cara memilih suhu yang tepat untuk penyimpanan tauge itu sendiri. Sehingga umur simpan tauge tidak bertahan lama, oleh karena itu perlu dilakukan penelitian agar didapatkan umur panen yang optimal dan suhu penyimpanan yang tepat untuk komoditi tauge.

\section{METODE PENELITIAN}

Penelitian ini dilaksanakan pada tanggal 11 Maret-29 Maret 2016 di Laboratorium Teknik Pasca Panen Prodi Teknik Pertanian dan Laboratorium Analisis Hasil Pertanian Prodi Teknologi Hasil Pertanian, Fakultas Pertanian Universitas Syiah Kuala, Darussalam-Banda Aceh.

\section{Alat dan Bahan}

Alat yang digunakan dalam penelitian ini adalah timbangan digital, refraktometer, thermometer, lemari pendingin, buret, labu ukur, Erlenmeyer, PH meter dan alat-alat gelas lainnya. Bahan yang digunakan dalam penelitian ini adalah tauge segar dan kemasan plastik Strech film dan Styrofoam.

\section{Prosedur Penelitian}

Persiapan tauge segar setelah dipanen pada umur 3, 5 dan 7 hari pertumbuhan kemudian dibersihkan dari kotoran yang menempel untuk menjaga kualitas pada saat penyimpanan, kemudian tauge di sortasi guna untuk mendapatkan ukurannya yang sama, setelah itu dilakukan penimbangan. Setelah tauge ditimbang maka dilakukan pengemasan. Pada tahap ini, tauge dikemas dalam kemasan plastik strech film. Setelah itu disimpan pada suhu $4^{\circ} \mathrm{C}$ dan $7^{\circ} \mathrm{C}$ dan suhu ruang.

\section{Susut Bobot}

Tauge diambil dari tempat penyimpanan dan kemudian ditimbang dengan timbangan digital. Sebelumnya timbangan diatur pada posisi 0.00 (Sudarmadji,1984),

\section{Total Padatan Terlarut}

Menurut Muchtadi dan Sugiyono (2010), total padatan terlarut (\%) dihitung dengan menggunakan Refraktometer Digital. Cara kerjanya adalah bahan dihancurkan dengan menggunakan kain tipis. Kemudian bahan disaring dengan menggunakan kertas saring kemudian disentrifuse, fitrasi dari bahan tersebut diteteskan pada prisma Refraktometer dan dibaca (\% Brix). 


\section{Vitamin C}

pengujian kadar vitamin $\mathrm{C}$ adalah dalam bentuk Asam Askobat. $25 \mathrm{ml}$ filtrate dititrasi dengan larutan iod $0,01 \mathrm{~N}$, ditambahkan indikator amilum pada filtrate. Sebelum filtrate dilakukan sampai terjadi perubahan warna yang stabil (terbentuk, warna putih kehijauan). (Sudarmadji, 1984)

\section{Uji Kalsium}

Prinsip uji kalsium dengan metode EDTA (Asam Etilen Diamin Tetra Asetat) yaitu pada pH 12-13 ion-ion kalsium bereaksi dan membentuk senyawa kompleks dengan EDTA yang kesetaraanya dapat diketahui dengan timbulnya warna ungu dari larutan murexi.

\section{Uji Organoleptik}

Menurut Soekarto (1985), Pengujian organoleptik/ sensorik dapat ditentukan dengan menggunakan indra manusia (secara visual). Uji organoleptik yang meliputi warna, aroma, dan penerimaan keseluruhan. Penilaian dilakukan dengan menggunakan skala hedonik berdasarkan kriteria sangat suka sampai tidak suka yang dikonversikan dalam angka (skor). Angka yang digunakan dalam skala hedonik terdiri atas 5 tingkat, yaitu: $5=$ Sangat suka, $4=$ Suka, $3=$ Netral, $2=$ Tidak suka, $1=$ Sangat tidak suka. Penilaian dilakukan oleh 20 orang panelis (mahasiswa) yang dianggap dapat mawakili konsumen dalam memberi nilai kesukaan terhadap tauge. Penilaian dilakukan selama penyimpanan dengan interval waktu 1 hari sekali hingga panelis menolak.

\section{Coefficient Of Performance (COP)}

Menurut Khalil (2007) koefisien performasi (COP) merupakan suatu nilai perbandingan antara kalor yang terdapat pada evaporator dengan daya yang terdapat pada kompresor. Perhitungannya untuk mengetahui kebutuhan energi di pendingin (refrigerator) yang digunakan untuk ketiga perlakuan suhu yaitu pada suhu pendingin $4^{\circ} \mathrm{C}$ dan $7^{\circ} \mathrm{C}$ dalam lemari kulkas dan suhu ruang.

\section{HASIL DAN PEMBAHASAN \\ Susut bobot}

Hasil penelitian menunjukkan bahwa perubahan persentase susut bobot pada hari penyimpanan ke-0 sampai 10 , berbeda-beda pada setiap perlakuan. Seperti yang terlihat pada Gambar 1. Susut bobot tauge meningkat seiring dengan lamanya penyimpanan untuk semua
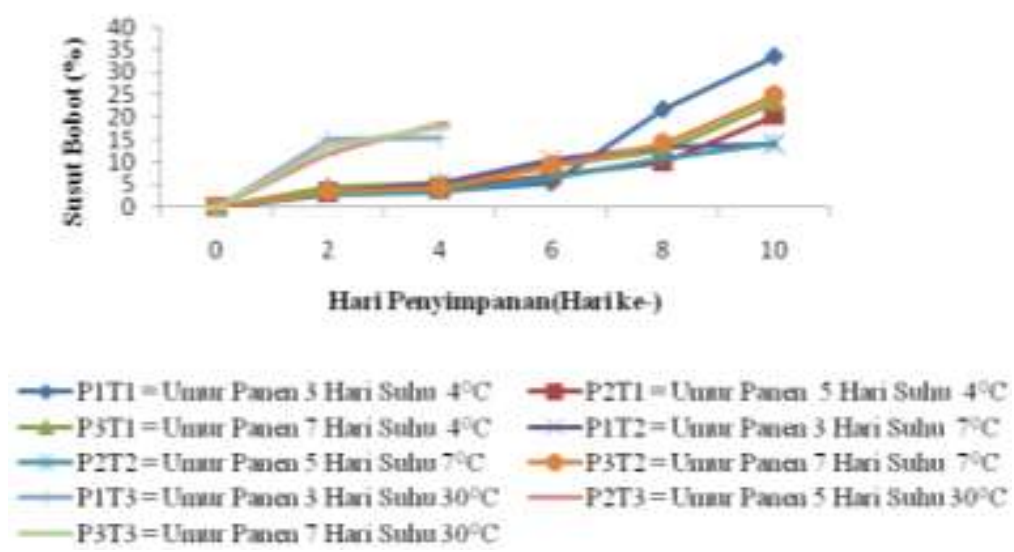
Gambar 1. Grafik Hubungan Susut Bobot Tauge untuk Semua Variasi UmurPanen Tauge dan Suhu Selama Penyimpanan.

Pada gambar 1 memperlihatkan persentase susut bobot yang terjadi pada tauge selama 10 hari penyimpanan. Tauge dengan variasi perlakuan suhu $4^{\circ} \mathrm{C}, 7^{\circ} \mathrm{C}$ dan $30^{\circ} \mathrm{C}$ menunjukkan peningkatan persentase susut bobot selama penyimpanan. Susut bobot tertinggi terjadi pada tauge dengan suhu penyimpanan $4^{\circ} \mathrm{C}$ dengan umur panen 3 hari yaitu sebesar 33,50\% (hari ke10), sedangkan persentase terkecil pada tauge dengan umur panen 3 hari yang disimpan pada suhu penyimpanan $7^{\circ} \mathrm{C}$ yaitu $2,80 \%$ pada hari ke- 2 . Pada hari ke 4 sampai hari ke 10 ketiga jenis variasi tauge yang disimpan pada suhu $30^{\circ} \mathrm{C}$ mengalami kebusukan.

\section{Total Padatan Terlarut}

Berdasarkan hasil penelitian terhadap total padatan Terlarut tauge untuk semua variasi umur panen dan suhu penyimpanan berkisar antara 15,6\% Brix - $3 \%$ Brix. Nilai total padatan terlarut tertinggi terjadi pada hari ke-0 tauge dengan umur panen 3 hari yang disimpan pada suhu $7^{\circ} \mathrm{C}$ dengan nilai $15,6 \%$ Brix. Sedangkan nilai terendah terjadi pada hari ke-10 tauge dengan umur panen 7 hari yang disimpan pada suhu $4^{\circ} \mathrm{C}$ dengan nilai $3 \%$ Brix. Grafik persentase total padatan terlarut dapat dilihat pada Gambar 6. Selama penyimpanan tauge menunjukkan perubahan persentase total padatan terlarut pada umur panen.

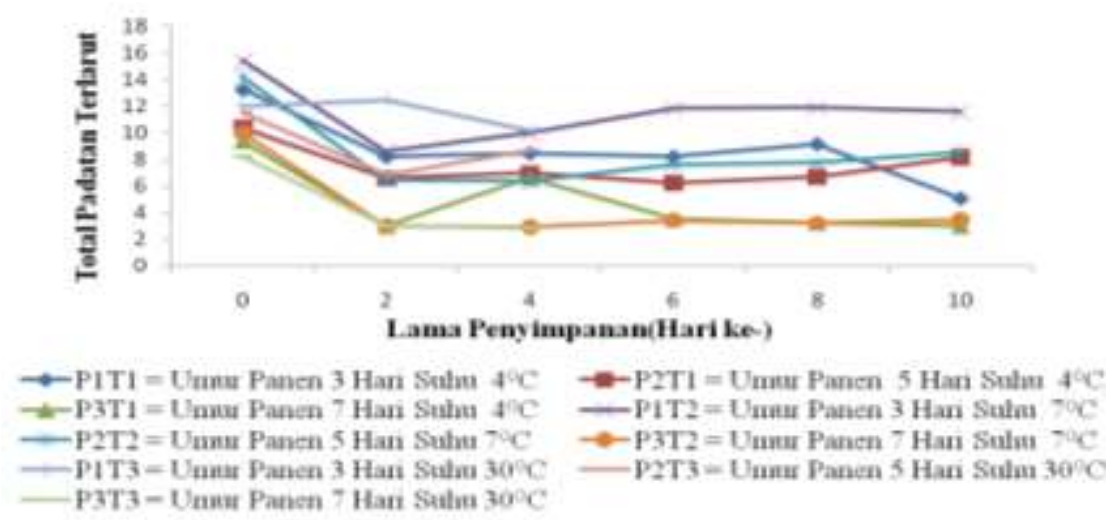

Gambar 2. Grafik Total Padatan Terlarut tauge untuk semua variasi umur panen tauge dan suhu selama penyimpanan.

\section{Vitamin C}

Penurunan kadar vitamin C selama penyimpanan menurut Winarno (1997), terjadi karena adanya proses oksidasi karena vitamin $\mathrm{C}$ sangat mudah teroksidasi menjadi asam Ldehidroaskobat yang cenderung mengalami perubahan lebih lanjut menjadi L-diktogulonat, sehingga tidak lagi memiliki keaktifan seperti vitamin $\mathrm{C}$ (asam askorbat).

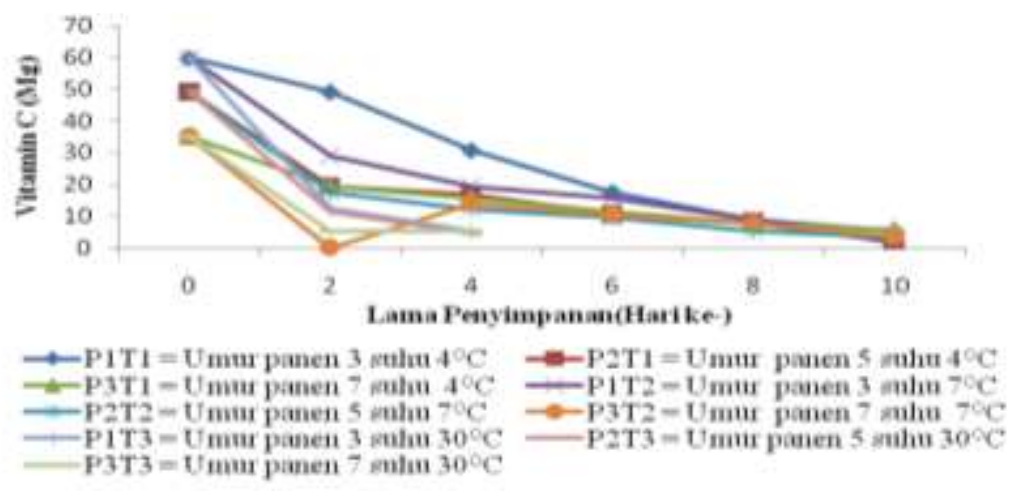


Gambar 3. Grafik vitamin C tauge untuk semua variasi umur panen tauge dan suhu selama penyimpanan.

\section{Kalsium}

Hasil penelitian menunjukkan bahwa tauge yang disimpan dengan variasi umur panen dan suhu penyimpanan semakin menurun seiring bertambahnya hari penyimpanan, hal ini disebabkan karena rusaknya dinding sel didalam tanaman sehingga mengakibatkan kadar kalsium semakin menurun selama penyimpanan.

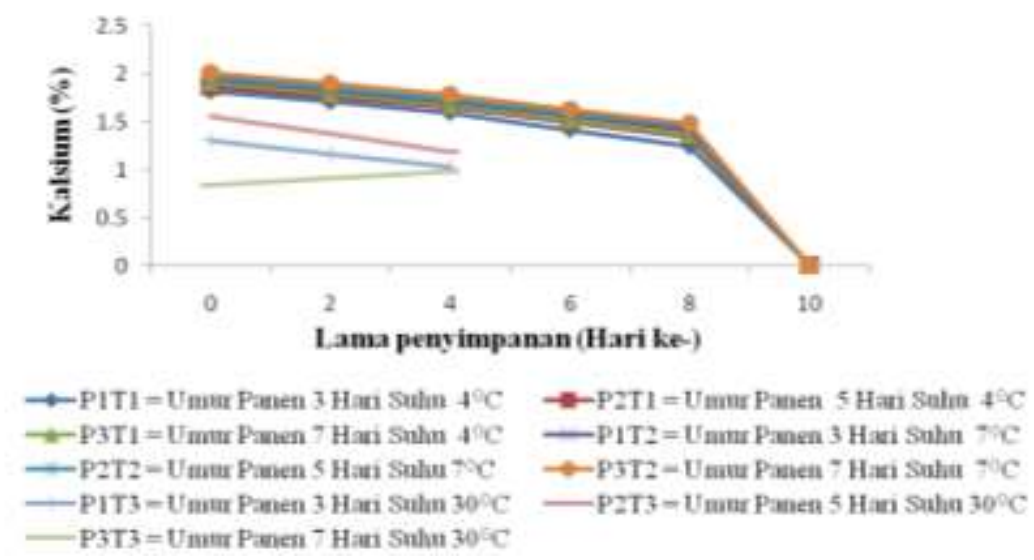

Gambar 4. Grafik Kalsium tauge untuk semua variasi umur panen tauge dan suhu selama penyimpanan

\section{Organoleptik}

Uji organoleptik dilakukan untuk mengetahui tingkat penerimaan konsumen terhadap tauge pada semua variasi perlakuan. Penilaian dilakukan dengan skala 1-5 menggunakan hedonic test. Penilaian dilakukan dua hari sekali hingga panelis menolak untuk semua variasi umurr panen dan suhu penyimpanan. Menurut Winarno (2000) Penentuan mutu bahan makanan yang umumnya sangat bergantung pada beberapa faktor antara lain warna, aroma, tekstur, dan nilai gizi.

Hasil uji organoleptik terhadap aroma, tekstur, warna dan penerimaan keseluruhan tauge yang disimpan dengan variasi umur panen pada suhu rendah $\left(4^{\circ} \mathrm{C}\right.$ dan $\left.7^{\circ} \mathrm{C}\right)$ dan suhu ruang $\left(30^{\circ} \mathrm{C}\right)$ cenderung menurun tingkat kesukaan seiring lamanya penyimpanan. Warna dapat mempengaruhi keputusan konsumen untuk menerima atau menolak suatu produk. Tauge dengan penampakan yang kurang menarik pasti akan ditolak oleh panelis, karena itu pengujian terhadap warna sangat perlu diperhatikan. Uji organoleptik pada penelitian ini menggunakan uji penerimaan menyangkut penilaian seseorang terhadap suatu sifat bahan sehingga menjadikannya kegemaran atau kesukaan. Untuk mengetahui nilai kesukaan konsumen dilakukan uji hedonik yang meliputi warna, aroma dan penerimaan keseluruhan.

\section{Coefficient Of Performance (COP)}

Perhitungan COP bertujuan untuk mengetahui kinerja pada mesin pendingin. Semakin tinggi suhu suatu bahan maka nilai COP akan semakin tinggi, jika semakin rendah suhu suatu bahan maka nilai COP semakin rendah. Menurut pendapat Ridwan (2005) perhitungan nilai COP diperlukan sebagai bentuk penilaian dari suatu mesin refrigerasi, semakin besar nilai COP 
menunjukkan bahwa kerja mesin tersebut semakin baik. Kenaikan kecepatan udara pendingin kondensor menyebabkan efek refrigerasi meningkat, sedangkan kerja kompresi mengalami penurunan sehingga nilai COP akan menjadi semakin naik. Konsep koefisiensi prestasi sama dengan efisiensi yang menyatakan perbandingan jumlah hasil yang diinginkan dengan pengeluaran. Nilai COP berbanding lurus dengan dampak refrigerasinya dan berbanding terbalik dengan kerja kompresinya. Nilainya semakin naik dengan peningkatan temperatur keluar evaporator. Kenaikan nilai COP dikarenakan pada kenaikan temperatur keluar evaporator menyebabkan kenaikan dampak refrigerasi dan menurunkan kerja kompresi sehingga kedua parameter tersebut memperbesar nilai COP.

Tabel 1. Hasil perhitungan nilai COP untuk penyimpanan tauge

\begin{tabular}{lllllll}
\hline $\begin{array}{l}\text { Suhu } \\
\left({ }^{\circ} \mathrm{C}\right)\end{array}$ & $\begin{array}{l}\mathrm{W} \\
(\mathrm{kW})\end{array}$ & $\begin{array}{l}\mathrm{qk} \\
(\mathrm{kW})\end{array}$ & Qev $(\mathrm{kW})$ & $\mathrm{m}(\mathrm{kg} / \mathrm{s})$ & Dilepaskan $(\mathrm{kj})$ & $\mathrm{COP}$ \\
\hline 4 & 0,06 & 0,203 & 0,1432 & 0,00089 & 236,6 & 2,36 \\
7 & 0,032 & 0,1109 & 0,078 & 0,00048 & 209,3 & 2,45 \\
\hline
\end{tabular}

Berdasarkan Tabel 1. Dapat diketahui apabila nilai energi yang dilepaskan semakin besar, maka kinerja kulkasnya tidak bagus. Jika dihubungkan dengan penelitian yang saya kaji, semakin bagus kinerja kulkasnya maka proses penyimpanan tauge akan terjaga mutunya dari kerusakan fisik. Tauge yang disimpan pada suhu dingin $4^{\circ} \mathrm{C}$ lebih rendah nilai $\mathrm{COP}$ dibandingkan dengan suhu $7^{\circ} \mathrm{C}$, karena semakin tinggi suhu suatu bahan yang diinginkan maka nilai COP semakin tinggi, namun semakin rendah suhu suatu bahan yang diinginkan maka nilai COP semakin rendah. Hal ini dapat dilihat dari hasil perhitungan nilai COP pada suhu $4^{\circ} \mathrm{C}$ dengan nilai 2,36 dan suhu $7^{\circ} \mathrm{C}$ dengan nilai 2,45 . Sedangkan energi yang dilepaskan awal pendinginan di kulkas berbanding terbalik dengan nilai COP, ini terbukti bahwa suhu $4^{\circ} \mathrm{C}$ nilai energi yang dilepaskan $236.6 \mathrm{~kJ}$ dan suhu $7^{\circ} \mathrm{C}$ nilai energi yang dilepaskan $209.3 \mathrm{~kJ}$. Disebabkan semakin rendah suhu yang dinginkan, semakin besar energi yang bekerja pada alat pendingin dan bahan mempunyai umur simpan yang lebih singkat sesuai dengan uji organoleptik dan total padatan terlarut, karena pada suhu $7^{\circ} \mathrm{C}$ mutu fisik tauge lebih bagus dari pada suhu $4^{\circ} \mathrm{C}$ dan total padatan terlarut tauge lebih tinggi pada suhu $7^{\circ} \mathrm{C}$ dari pada suhu $4^{\circ} \mathrm{C}$. apabila suhunya rendah sekitar $7^{\circ} \mathrm{C}$ dan umur panennya 3 hari, mutu fisik tauge akan bertahan. Dari hasil penelitian ini belum terlihat secara jelas hubungan antara umur panen dengan nilai COP, karena nilai COP itu hanya ada hubungan dengan suhu penyimpanan.

\section{KESIMPULAN DAN SARAN}

Perlakuan terbaik tauge selama penyimpanan 10 hari terdapat pada variasi umur panen 3 hari pada suhu $7^{\circ} \mathrm{C}$ dengan persentase susut bobot suhu dingin $14,00 \%$, total padatan terlarut $11,55 \%$ Brix, Vitamin C 5,77 mg, Kalsium 0,21\%, organoleptik warna 3,75, organoleptik aroma 3,55 dan organoleptik penerimaan keseluruhan 3,55. Suhu $7^{\circ} \mathrm{C}$ dengan freon 134 -a nilai COP (Coefficient of Performance) yang didapatkan lebih besar yaitu 2,45 dibandingkan pada suhu $4^{\circ} \mathrm{C}$ dengan nilai 2,36 dan energi yang dilepaskan awal pendinginan yang bekerja suhu $4^{\circ} \mathrm{C}$ dengan jumlah nilai $236,6 \mathrm{~kJ}$ lebih besar dari pada suhu $7^{\circ} \mathrm{C}$ dengan jumlah nilai $209,3 \mathrm{~kJ}$. 


\section{Saran}

Diharapkan adanya penelitian lebih lanjut dengan menggunakan tauge serta menggunakan merek kulkas yang sama.

\section{DAFTAR PUSTAKA}

Ashari, S. 2006. Hortikultura Aspek Budidaya. Universitas Indonesia-Press, Jakarta.

Khalil, M. 2007. Simulasi Model Perpindahan Panas Pada Evaporator Mesin Pendingin Sistem Kompresi Uap Untuk Penyimpanan Sayuran. Skripsi. Program Studi Teknik Pertanian, Fakultas Pertanian, Universitas Syiah Kuala, Banda Aceh.

Maulana, 2010. Pengaruh ekstrak tauge (Phaseolus radiatus) terhadap kerusakan sel ginjal mencit (Mus musculus) yang diinduksi parasetamol. Fakultas Kedokteran, Universitas Sebelas Maret, Surakarta.

Muchtadi, T.R., Sugiyono, Ayustaningwarno F. 2010. Ilmu Pengetahuan Bahan Pangan. Alfabeta, Bandung.

Ridwan.2005. Perbandingan Untuk Kerja Freon R-12 Dan R-13a Terhadap Variasi Beban Pendinginan Pada Sistem Refrigerator 75 W. Prosiding Seminar Nasional "TTMIV" hasil penelitian Universitas Gunadarma "Teknologi Industri” Depok. Hal:75-76.

Setyadjit, S. 1992. Pengaruh Ketebalan Plastik untuk Penyimpanan Atmosfer Termodikasi Mangga Cv. Arumanis dan Indramayu. Jurnal Hortikultura.2:31-42.

Soekarto,1985. Penelitian Organoleptik untuk Industri Pangan dan Hasil Pertanian. Bharata Karya Aksara, Jakarta.

Sudarmadji,S.B.1984. Prosedur Analisa untuk Bahan Makanan dan Pertanian. Liberty, Jakarta.

Winarno, F.G. 2000. Teknoloi Pasca Panen Jamur, Pengawetan dan Pengolahannya. Makalah Penelitian Budidaya Jamur Kayu. Kerjasama Mbrio Food Laboratory dengan pusbang tepa LPM IPB. Bogor.

Winarrno.1997. Kimia Pangan dan Gizi. PT. Gramedia Pustaka Utama, Jakarta. 